\title{
Potential Down-Regulation of Salivary Gland AQP5 by LPS via Cross-Coupling of NF- $\kappa$ B and p-c-Jun/c-Fos
}

\author{
Chenjuan Yao, ${ }^{*}$ Nunuk Purwanti, ${ }^{*}$ \\ Mileva Ratko Karabasil, ${ }^{*}$ Ahmad Azlina, ${ }^{*}$ \\ Purevjav Javkhlan, ${ }^{* \dagger}$ Takahiro Hasegawa, ${ }^{*}$ \\ Tetsuya Akamatsu, ${ }^{*}$ Toru Hosoi, ${ }^{\ddagger}$ \\ Koichiro Ozawa, ${ }^{\ddagger}$ and Kazuo Hosoi* \\ From the Departments of Molecular Oral Physiology, ${ }^{*}$ and \\ Periodontology and Endodontology, ${ }^{\dagger}$ Institute of Health \\ Biosciences, The University of Tokushima Graduate School, \\ Tokushima-shi, Tokushima; and the Department of \\ Pharmacotherapy,,$^{\ddagger}$ Graduate School of Biomedical Sciences, \\ Hiroshima University, Hiroshima, Japan
}

The mRNA and protein levels of aquaporin (AQP)5 in the parotid gland were found to be potentially decreased by lipopolysaccharide (LPS) in vivo in $\mathrm{C} 3 \mathrm{H}$ / HeN mice, but only weakly in C3H/HeJ, a TLR4 mutant mouse strain. In the LPS-injected mice, pilocarpine-stimulated saliva production was reduced by more than $50 \%$. In a tissue culture system, the LPSinduced decrease in the AQP5 mRNA level was blocked completely by pyrrolidine dithiocarbamate, MG132, tyrphostin AG126, SP600125, and partially by SB203580, which are inhibitors for IKB kinase, 26S proteasome, ERK1/2, JNK, and p38 MAPK, respectively. In contrast, the expression of AQP1 mRNA was down-regulated by LPS and such down-regulation was blocked only by SP600125. The transcription factors NF- $k$ B (p65 subunit), p-c-Jun, and c-Fos were increased by LPS given in vivo, whereas the proteinbinding activities of the parotid gland extract toward the sequences for NF- $\kappa$ B but not AP-1-responsive elements present at the promoter region of the $A Q P 5$ gene were increased by LPS injection. Co-immunoprecipitation by using antibody columns suggested the physical association of the three transcription factors. These results suggest that LPS-induced potential down-regulation of expression of AQP5 mRNA in the parotid gland is mediated via a complex(es) of these two classes of transcription factors, NF- $\kappa \mathrm{B}$ and p-c-Jun/c-Fos. (Am J Pathol 2010, 177:724-734; DOI: 10.2353/ajpath.2010.090282)
Aquaporins (AQPs), the family of water channels, play a fundamental role in transmembrane water movements in microorganisms, plants, and animal tissues. To date, 13 members are known to belong to this channel family in mammalians; they are designated AQP0-12. ${ }^{1}$ AQPs are found not only in the tissues where the rapid and regulated transport of fluid is necessary but also in many other tissues where water channels play a fundamental role in water metabolism. Several studies suggest that the function of some members of the AQP family is hormonally regulated and that defects in their expression and/or trafficking result in diseases in which fluid transport is altered. ${ }^{2}$ For example, knockout or disruption of various $A Q P$ genes results in permeability changes leading to diseases in the kidney, lens, lacrimal, salivary, and sweat glands in both animals and humans. ${ }^{3-6}$ Thus, nephrogenic diabetes insipidus develops as a consequence of mutations in the AQP2 gene; and cataract, when mutations occur in AQP0., ${ }^{7,8}$ AQP5 was first identified in the salivary gland, ${ }^{9}$ and its mutant rat and knockout mice show decreased saliva production with altered composition. ${ }^{10,11}$ Recently, multiple AQPs were reported to be regulated under pathophysiological conditions, and the abnormal or lack of expression of AQP1, AQP2, AQP3, and AQP4 is associated with a number of water-balance disorders in the kidney. ${ }^{12,13}$

The endotoxin lipopolysaccharide (LPS) is the major constituent of the outer envelope of Gram-negative bacteria, ${ }^{14}$ which is thought to be a cause of the widespread cellular activation observed in patients with Gram-nega-

Supported by Grant-in-Aid for Scientific Research No. 20791353 and 18390493 from the Ministry of Education, Culture, Sports, Science, and Technology of Japan.

Accepted for publication April 7, 2010.

Current address of C.Y.: The Department of Medicine and Physiology, Cardiovascular Research Institute, Health Science, University of California San Francisco, CA; of N.P.: Department of Basic Dental Science, Faculty of Dentistry, Gadjah Mada University, Yogyakarta, Indonesia; of M.R.K.: Department of Orthodontics, Faculty of Dentistry, Belgrade University, Belgrade, Serbia.

Address reprint requests to Prof. Kazuo Hosoi, Ph.D., Department of Molecular Oral Physiology, Institute of Health Biosciences, The University of Tokushima Graduate School, 3-18-15, Kuramoto-Cho, Tokushima-Shi, Tokushima 770-8504, Japan. E-mail: hosoi@dent.tokushima-u.ac.jp. 
tive septic shock. LPS-induced activation of pro-inflammatory cytokines and antipeptides, such as interleukin-6 and defensin, is mediated by the interaction of LPS with membrane receptors including Toll-like receptor 4 (TLR4), CD14, or CD11/CD18. These molecules are suggested to be associated with one another on the plasma membrane. ${ }^{15,16}$ However, CD14 does not have a transmembrane domain, ${ }^{15-17}$ and CD11/CD18 does not appear to transduce a signal directly, ${ }^{18}$ suggesting that TLR4 is the functional LPS signal transducer. ${ }^{19,20} \mathrm{Be}-$ cause it remains unknown whether the regulation of salivary gland AQPs is influenced by LPS, which is closely related to inflammation, we investigated the effects of LPS on the expression of AQP5 and AQP1 in the submandibular gland (SMG) and parotid gland (PG) of mice.

Signals from the TLR family of microbial sensors are essential for generating innate immune responses to a broad range of pathogens. ${ }^{14}$ Ligand binding to the extracellular domain of TLRs initiates a complex signaltransduction cascade, which ultimately leads to activation of the transcription factor NF- $\kappa \mathrm{B}$ and increases the transcription of various pro-inflammatory cytokines. In LPS signaling, the NF- $\kappa \mathrm{B}$ pathway is of undoubted importance, but the role of MAPK pathways has remained to be determined. The MAPK pathways consist of three members: i) ERK1/2, which is activated by chemoattractants and growth factors, ii) JNK, and iii) p38 MAPK, which are stress- and cytokine-activated. ${ }^{21}$ These signaling pathways are involved also in the inflammatory response and are activated through well-described signaling cascades. ${ }^{22}$

Water secretion as well as cytokine secretion from the salivary gland is important for protecting the host from microorganisms. ${ }^{5,11} \mathrm{AQP}$ in the plasma membrane of mammalian cells allows rapid and regulated water movement in response to osmotic changes in the cellular environment. Because lung AQPs have been reported to be influenced by acute viral infection, ${ }^{23}$ salivary gland AQPs may be altered under certain pathological conditions as well. We therefore hypothesized that the gene expression of $A Q P 5$ and $A Q P 1$ in the $S M G$ and $P G$ may be regulated by LPS released during inflammation.

In this study, we show that LPS strongly down-regulates AQP5 mRNA expression via NF- $\kappa$ B and MAPK pathways and suggest that two classes of transcription factors, NF- $\kappa \mathrm{B}$ and $\mathrm{p}$-c-Jun/c-Fos, are synergistically involved (cross-coupling) in this potentiation.

\section{Materials and Methods}

\section{Reagents}

Pyrrolidine dithiocarbamate (PDTC), MG132, SB203580, tyrphostin AG126, and SP600125 were obtained from Sigma-Aldrich (St. Louis, $\mathrm{MO}$ ). $\mathrm{NO}_{2} / \mathrm{NO}_{3}$ Assay Kit-FX was purchased from Dojindo Laboratories (Kumamoto, Japan). Medium 199 was obtained from Nissui (Tokyo, Japan); and a one-step SYBER ${ }^{\circledR}$ PrimeScript RT-PCR kit (Perfect Real Time) from TAKARA BIO INC (Shiga, Japan). Polyclonal goat anti-TLR4, goat anti-AQP5, rabbit anti-human NF- $\kappa$ B p65 subunit, goat anti-human c-Fos, rabbit IgG against p-c-Jun (phosphorylated c-Jun at both Ser 63 and Ser 73), rabbit anti-human NF- $\kappa$ B p50, and the blocking solutions for these antibodies were purchased from Santa Cruz Biotechnology (Santa Cruz, CA). Polyclonal rabbit anti-phospho-p44/42 MAPK (p-ERK1/2; Thr202/Tyr204) and anti-p44/42 MAPK (ERK1/2) antibodies were from Cell Signaling Technology, Inc. (Danvers, $M A)$. Poly (dl-dC) was obtained from Amersham Biosciences (Piscataway, NJ). Alexa Fluor 594 donkey antigoat IgG $(\mathrm{H}+\mathrm{L})$ was from Molecular Probes (Invitrogen, OR). Double-stranded DNA probes end-labeled with DIG were obtained from Hokkaido System Science Co., LTD (Hokkaido, Japan). All other regents were procured as described previously. ${ }^{24,25}$

\section{Animal Experiments}

Male $\mathrm{C} 3 \mathrm{H} / \mathrm{HeN}, \mathrm{C} 3 \mathrm{H} / \mathrm{HeJ}$, and $\mathrm{C} 57 \mathrm{BL} / 6\left(\mathrm{TLR}_{4}^{+/+}\right)$mice at the age of 7 to 8 weeks were purchased from Japan SLC (Shizuoka, Japan). Three pairs of C57BL/6 $\left(\mathrm{TLR}^{-1-}\right)$ mice were obtained from OrientalBioService, Inc. (Kyoto, Japan); they were mated in our animal facility to obtain offsprings. All animals were housed under standard conditions. They were sacrificed for experiments at the age of 8 to 9 weeks. LPS dissolved in saline was injected i.p. at a dose of 100 $\mu \mathrm{g} / 0.1 \mathrm{ml} /$ mouse. In all in vivo experiments, each group consisted of at least four mice.

The saliva secretion was provoked by pilocarpine injection ( $1 \mathrm{mg} / \mathrm{kg}$ body weight, i.p.). The saliva from nontreated and LPS-treated (24 hours) $\mathrm{C} 3 \mathrm{H} / \mathrm{HeN}, \mathrm{C} 3 \mathrm{H} / \mathrm{HeJ}$, C57BL/6 $\left(\mathrm{TLR}^{+/+}\right)$, and C57BL/6 (TLR4 ${ }^{-1-}$ ) mice was collected by absorption into preweighed small cotton pellet in the preweighed $1.5 \mathrm{ml}$-Eppendorf tube, ${ }^{24}$ and their weights were immediately measured. From $\mathrm{C} 3 \mathrm{H} /$ $\mathrm{HeN}, \mathrm{C} 3 \mathrm{H} / \mathrm{HeJ}, \mathrm{C} 57 \mathrm{BL} / 6\left(\mathrm{TLR}_{4}^{+/+}\right)$, and C57BL/6 $\left(\mathrm{TLR}^{-1-}\right)$ mice, the sera before and after LPS-treatment (24 hours) were obtained and saved at $-80^{\circ} \mathrm{C}$.

The protocol applied for the present animal experiment was approved by the Institutional Review Board of the Animal Committee of the University of Tokushima.

\section{Tissue Culture of the PG}

$\mathrm{C} 3 \mathrm{H} / \mathrm{HeN}$ mice were sacrificed, and their PGs were rapidly dissected out and immersed immediately in ice-cold medium (Medium 199, containing 10 mmol/L HEPES, $200 \mathrm{U} / \mathrm{ml}$ penicillin $\mathrm{G}$, and $200 \mu \mathrm{g} / \mathrm{ml}$ streptomycin; $\mathrm{pH}$ 7.4). After having been washed three times with the above medium, the glands were carefully freed from connective tissue and lymph nodes under a stereomicroscope and cut into small pieces (about $1 \mathrm{~mm}^{3}$ ). The tissue pieces were then explanted onto siliconized lens papers, ${ }^{26}$ which were floated on the culture medium (Medium 199, pH 7.4, containing 200 $\mathrm{U} / \mathrm{ml}$ penicillin G, $200 \mu \mathrm{g} / \mathrm{ml}$ streptomycin, and $10 \mathrm{mU} / \mathrm{ml}$ insulin). The explanted tissues were precultured overnight $\left(37^{\circ} \mathrm{C}, 5 \% \mathrm{CO}_{2}\right)$. For the time-course study, LPS at a final concentration of $1 \mu \mathrm{g} / \mathrm{ml}$ was added to the culture medium in the tissue culture system at $0,18,21$, or 23 hours, and the tissue explants were collected at 24 hours. Thus these 
tissues were cultured for a total of 24 hours, with the tissue exposed to LPS for 0, 1, 3, 6 or 24 hours. For dose-response study, the tissues were incubated with LPS for 6 hours. For inhibitor studies, the appropriate concentrations of various inhibitors were added, and the tissues were preincubated for 1 hour. LPS ( $1 \mu \mathrm{g} / \mathrm{ml})$ was then added, and the explants were incubated for 6 hours.

All inhibitors were dissolved in dimethyl sulfoxide (DMSO) or normal saline. Cultures given the equivalent amount of DMSO (the final concentration $0.1 \%$ ) or normal saline were regarded as controls. The concentrations of inhibitors used in the present study were as follow: PDTC and AG126, $100 \mu \mathrm{mol} / \mathrm{L} ; \mathrm{MG} 132$, SB203580, and SP600125, $20 \mu \mathrm{mol} / \mathrm{L}$.

\section{Preparation of Total RNA and RT-PCR}

Total RNA was isolated from PG, SMG, cultured PG tissues, and bladder; and RT-PCR was performed as described previously. ${ }^{24,25}$ The primers, designed from mouse AQP5 and AQP1 sequences, were as follows: 5'-CCGAGACTTAGGTGGCTCAG-3' (sense) and 5'-AGCGACTTCACAGACCGCAT-3' (anti-sense) for mAQP1 (GenBank/NCBI Data Bank; accession number, NM007472); and 5'GGCCACATCAATCCGGCCATTA-3' (sense) and 5'GGCTGTTCCATGAACCCAGCC-3' (anti-sense) for mAQP5 (GenBank/NCBI Data Bank; accession number, NM009701). $\beta$-actin and mTLR4 were amplified, as described previously. ${ }^{24}$

\section{Real-Time RT-PCR Analysis}

Real-time RT-PCR was performed by using a one-step SYBER ${ }^{\circledR}$ PrimeScript RT-PCR kit (Perfect Real Time) as described previously, ${ }^{27}$ except that the template RNAs used were $10 \mathrm{ng}$. The sequences of PCR primers were described previously. ${ }^{27}$ The relative mRNA amount for AQP5 and AQP1 was calculated and normalized on the basis of the amount of $\beta$-actin.

\section{Anti-AQP5 and Anti-AQP1 Antisera}

The anti-AQP5 and anti-AQP1 antisera used for Western blotting were raised in rabbits immunized against keyhole limpet hemocyanin conjugated to synthetic peptides, $\mathrm{NH}_{2}-$ CDHREERKKTIELTAH-COOH and $\mathrm{NH}_{2}$-CEEYDLDADDINSRVEMKPK-COOH, which correspond to the C-terminal sequences of the respective water-channel proteins. Specificities of these antisera were confirmed previously. ${ }^{10}$

\section{Preparation of the Total Membrane Fraction, Cytosolic Proteins, and Nuclear Extracts}

The total membrane fractions of the PG and SMG dissected from $\mathrm{C} 3 \mathrm{H} / \mathrm{HeN}$ and $\mathrm{C} 3 \mathrm{H} / \mathrm{HeJ}$ mice at 0,6 , and 24 hours after LPS injection were prepared as described previously. ${ }^{27}$ To obtain cytosol proteins, the PG, SMG, and bladder from nontreated $\mathrm{C} 3 \mathrm{H} / \mathrm{HeN}$ mice were homogenized in the buffer described previously ${ }^{25}$ and the homogenate was centrifuged at $12,000 \times g$ for 30 minutes at $4^{\circ} \mathrm{C}$ to obtain the supernatant. The $P G$ extract containing nuclear proteins (nuclear extracts) was prepared as described by Chandrasekar et $\mathrm{al}^{28}$; ie, the $P G$ tissues from $\mathrm{C} 3 \mathrm{H} / \mathrm{HeN}$ mice at $0,0.5,1,3$, and 6 hours after injection of LPS were homogenized in the buffer referenced above and centrifuged at $12,000 \times g$ for 10 minutes at $4^{\circ} \mathrm{C}$ to recover the supernatant. The concentration of protein in all these samples was determined by using a Bio-Rad protein assay kit and stored at $-80^{\circ} \mathrm{C}$.

\section{Electrophoretic Mobility Shift Assay for NF- $\kappa B$}

Electrophoretic mobility shift assay (EMSA) was performed as described previously. ${ }^{28}$ Double-stranded DNA probes for two consensus sequences (5'-AGTCTCAGGCACTTCCCTAAGCC-3' and 5'-ACTCCCGATCCACTCCCCCGCTCC-3') of NF- $\kappa$ B (GenBank/NCBI Data Bank, accession number, AF087655) present in AQP5 promoter were end-labeled with DIG (custom ordered from Hokkaido System Science Co., LTD, Japan) and used for EMSA as probes (designated as probe 1 and probe 2, respectively). Each nuclear extract $(50 \mu \mathrm{g})$ was added to the binding buffer containing $1 \mu \mathrm{g}$ poly $(\mathrm{dl}-\mathrm{dC})$ and $0.05 \mu \mathrm{g}$ probe to make a total volume of $20 \mu \mathrm{l}$, and the mixture was then incubated at room temperature for 20 minutes. In experiments to show the specific DNA binding, 50x excess cold probes or anti-p65 antibody was mixed with the extract before the addition of the labeled probes; and the mixture was preincubated at room temperature for 30 minutes. Samples were loaded onto $4 \%$ polyacrylamide gels and electrophoresed at $15 \mathrm{~mA} / \mathrm{gel}$ on ice. The protein-DNA complexes on the gel were transferred onto a nylon filter (Amersham Hybond- ${ }^{+}$, GE Healthcare UK, Backinghamshire, UK) by a semidry method. The DNA on the blotted filter was detected by using a DIG Luminescent Detection kit for Nucleic Acids (Roche Applied Science, Tokyo, Japan) according to the manufacturer's protocol.

\section{Western Blotting}

The total membrane fraction (for AQP5, AQP1, and actin), nuclear extract (for p65, p-C-Jun, c-Fos, ERK1/2, and p-ERK1/2), and cytosolic protein (for TLR4) was mixed with $2 \times$ SDS sample buffer and incubated at $37^{\circ} \mathrm{C}$ for 30 minutes (for AQP1 and AQP5) or at $85^{\circ} \mathrm{C}$ for 15 minutes (for p65, p-c-Jun, c-Fos, TLR4, actin, ERK1/2, and p-ERK1/2). The samples for analysis of AQPs and c-Fos were subjected to $12 \%$ and $8 \%$ polyacrylamide gels, respectively; whereas those for other analyses were subjected to $10 \%$ polyacrylamide gel. The amounts of samples applied for electrophoresis were as follows: $0.2 \mu \mathrm{g}$ and $5 \mu \mathrm{g}$ of total membrane fraction for AQP5 and AQP1, respectively; $20 \mu \mathrm{g}$ of total membrane fraction for actin; $25 \mu \mathrm{g}$ of cytosolic proteins for p65 and TLR4; $60 \mu \mathrm{g}$ of nuclear extract for C-Fos, and $30 \mu \mathrm{g}$ of nuclear extract for p65, p-c-Jun, ERK1/2, and p-ERK1/2. After electrophoresis and blotting, all filters were blocked with 3\% nonfat dry milk in $0.1 \%$ T-PBS (PBS containing 0.1\% Tween-20) at room temperature for 2 hours and then incubated 
overnight at $4^{\circ} \mathrm{C}$ with primary antibody. The dilution of primary antisera or antibodies used was as follows: rabbit anti-AQP5, 3000X; rabbit anti-AQP1, rabbit anti-actin, rabbit anti-ERK1/2, or rabbit anti-p-ERK1/2, 1000x; goat anti-TLR4, goat anti-c-Fos, rabbit anti-p65, and rabbit anti-p-c-Jun, $0.4 \mu \mathrm{g} / \mathrm{ml}$. All primary antisera/antibodies were diluted with $1 \%$ nonfat dry milk in $0.1 \%$ T-PBS. For a control reaction, the filter was incubated with the same concentration of antiserum or antibody which had been preabsorbed with the blocking peptides. ${ }^{24,25}$ The filter was washed with $0.1 \%$ T-PBS, incubated with $3000 \times$ diluted donkey anti-rabbit IgG-HRP or with donkey antigoat IgG-HRP followed by washing with $0.1 \%$ T-PBS. The filter was then reacted with Enhanced Chemical Luminescence reagents (GE Healthcare UK).

\section{Nitrite Assay}

Aliquots of $50 \mu$ l sera were mixed with $450 \mu$ PBS and placed on the 10K Amicon Ultra-0.5 filter. The sample was then centrifuged to remove macromolecular complexes. The filtered sera were used for $\mathrm{NO}_{2}$ or $\mathrm{NO}_{2} / \mathrm{NO}_{3}$ assay by using the $\mathrm{NO}_{2} / \mathrm{NO}_{3}$ Assay Kit-FX following manufacturer's instructions. Fluorescence was measured using a microplatereader (Thermo Fisher, Nippon Thermo Co., Ltd.) with excitation and emission wavelengths at 365 and $460 \mathrm{~nm}$, respectively.

\section{Immunohistochemistry}

The PG frozen sections were prepared from $\mathrm{C} 3 \mathrm{H} / \mathrm{HeN}$ mice sacrificed at 0, 6, and 24 hours after the LPS injection and stained for AQP5 as described previously. ${ }^{10}$ To localize transcription factors, double immunostaining was performed using the frozen sections prepared from mice injected with LPS 1 hour before sacrifice or cultured tissues harvested at 1 hour after treatment with inhibitors and/or LPS. They were fixed further in a 1:1 mixture of ethanol and acetone at $-20^{\circ} \mathrm{C}$ for 5 minutes, and blocked with $5 \%$ donkey normal serum in PBS at room temperature. They were next immunoreacted with a mixture of 0.4 $\mu \mathrm{g} / \mathrm{ml}$ goat anti-AQP5 antibody and $2 \mu \mathrm{g} / \mathrm{ml}$ rabbit antip65 antibody, rabbit anti-p-c-Jun antibody, or $0.5 \mu \mathrm{g} / \mathrm{ml}$ rabbit anti-p50 antibody in 1\% donkey normal serum at $4^{\circ} \mathrm{C}$ overnight. After having been washed with PBS, the sections were reacted with $200 \times$ diluted fluorescein isothiocyanate (FITC)-conjugated affinity-purified donkey anti-goat $\lg G(\mathrm{H}+\mathrm{L})$ and $500 \times$ diluted Alexa Fluor 594 donkey anti-rabbit IgG $(\mathrm{H}+\mathrm{L})$ at room temperature for 2 hours. They were subsequently washed, counterstained with DAPI (4',6-diamidino-2-phenylindole), and examined with a fluorescence microscope (Nikon, Tokyo, Japan).

\section{Immunoprecipitation}

Antibodies and normal IgGs $(40 \mu \mathrm{g})$ were cross-linked to $380 \mu \mathrm{l}$ of $50 \%$ Protein G Sepharose 4 Fast Flow (Amersham Biosciences) by using dimethyl pimelimidate- $\mathrm{HCl}$ according to the manufacturer's directions (Pierce Bio-

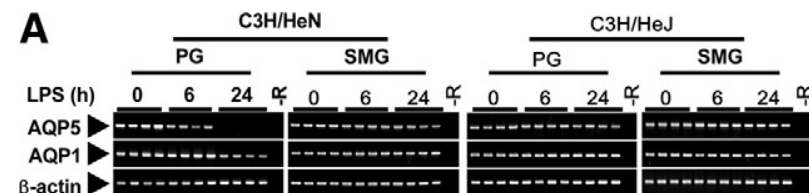

B

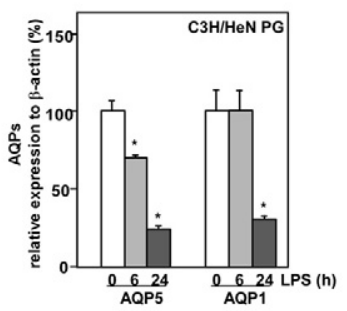

D
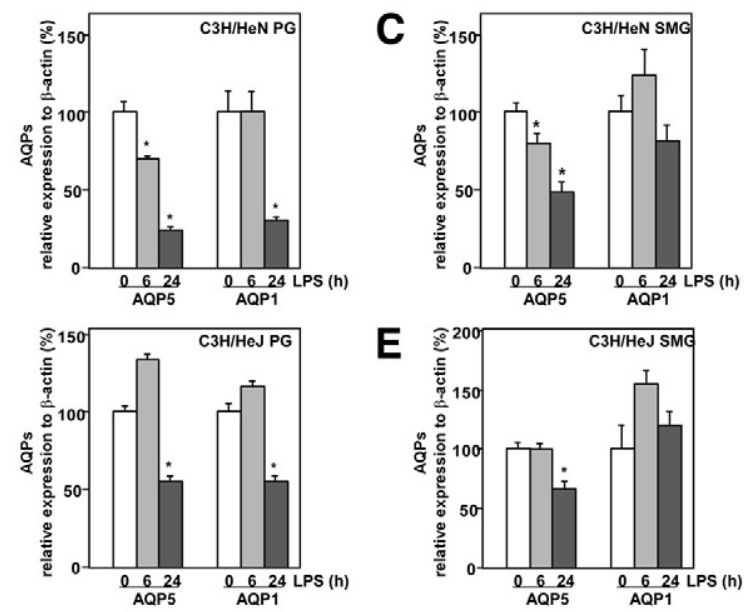

E

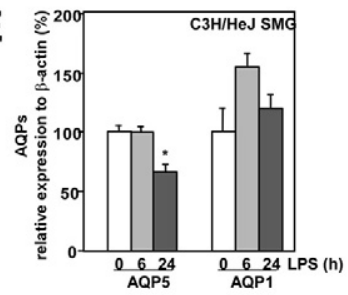

$\mathbf{F}$
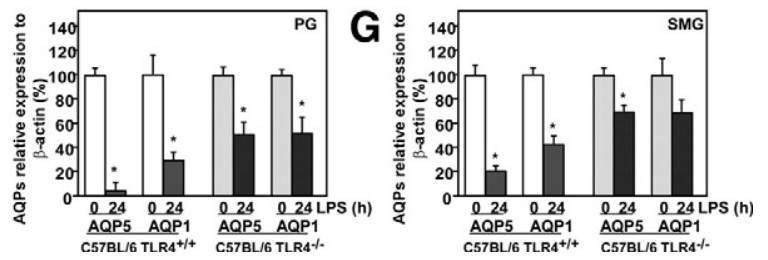

Figure 1. Effects of LPS on expression of AQP5 and AQP1 mRNAs in the PG and SMG. A: Agarose electrophoresis of RT-PCR products. $-\mathrm{R}$ indicates no added RNA. B-G: mRNA analysis by real-time RT-PCR. A-E: Analysis of mRNA prepared from $\mathrm{C} 3 \mathrm{H} / \mathrm{HeN}$ and $\mathrm{C} 3 \mathrm{H} / \mathrm{HeJ}$ mice. $\mathbf{F}$ and $\mathbf{G}$ : Analysis of

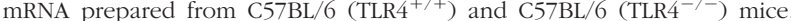
Data are presented as the mean \pm SE of 4 mice. ${ }^{*} P<0.05$, significantly different from the control ( 0 hours).

technology, Rockford, IL). The nuclear extracts from LPStreated mice (3 hours) were incubated with antibodycoupled Sepharose at $4^{\circ} \mathrm{C}$ overnight. The columns were washed, and the protein bound was eluted. The eluate was immediately neutralized and then processed for Western blot analysis.

\section{Statistic Analysis}

Results were presented as means \pm SE. Data for time course and dose response studies of mRNA (real-time RT-PCR) were statistically analyzed by one-way analysis of variance followed by Mann-Whitney's U-test. Data for other experiments were analyzed by Student's $t$-test.

\section{Results}

\section{Effects of LPS on Expression of $m R N A$ As and Proteins for AQP5 and AQP1 in the PG and $S M G$ in Vivo}

To determine whether the expression of AQP5 and AQP1 in the PG would be affected by LPS, we injected mice with LPS at a dose of $100 \mu \mathrm{g} / \mathrm{mouse}$ i.p. and sacrificed 
A

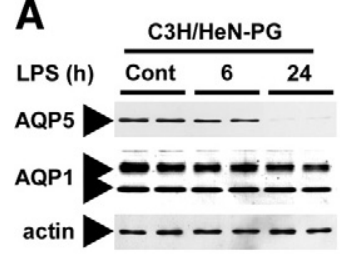

B

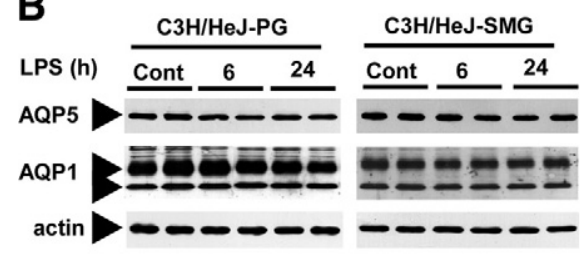

D

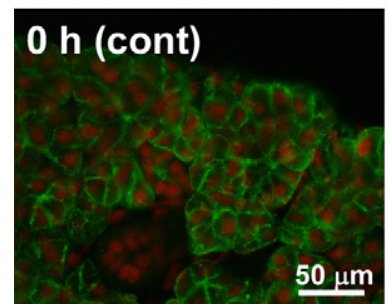

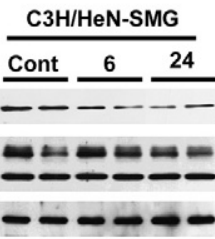

C3H/HeJ-SMG

Cont

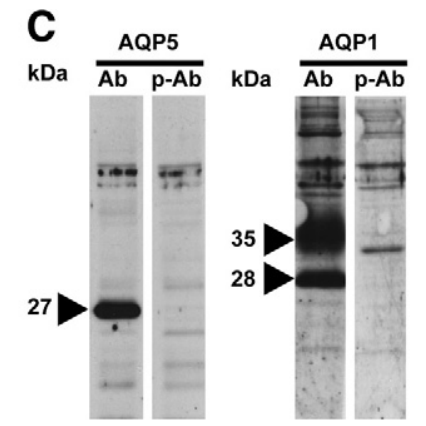

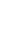

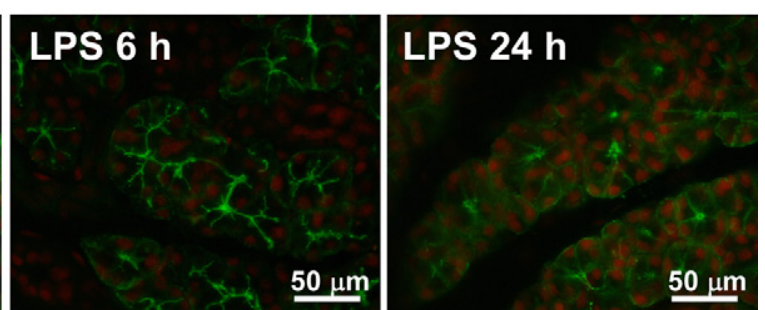

Figure 2. Effects of LPS on expression of AQP5 and AQP1 proteins in the PG and SMG from $\mathrm{C} 3 \mathrm{H} / \mathrm{HeN}$ and $\mathrm{C} 3 \mathrm{H} / \mathrm{HeJ}$ mice. A: $\mathrm{C} 3 \mathrm{H} / \mathrm{HeN}$ mice. B: $\mathrm{C} 3 \mathrm{H} / \mathrm{HeJ}$ mice. C: Control experiment using the total membrane fraction of the PG from nontreated $\mathrm{C} 3 \mathrm{H} / \mathrm{HeN}$ mice. $\mathrm{Ab}$ indicates antisera; p-Ab, peptide-preabsorbed antisera. $\mathbf{D}$ : Immunohistochemical detection of AQP5 in the PG of $\mathrm{C} 3 \mathrm{H} / \mathrm{HeN}$ mice that had been injected with LPS at 0,6 , and 24 hours before sacrifice (left, middle, and right pictures, respectively) Green indicates FITC immunofluorescence showing subcellular localization of AQP5; red, propidium iodide showing cell nuclei. them after various time periods. By RT-PCR and real-time RT-PCR analysis, a prominent decrease in AQP5 and AQP1 mRNA levels was observed in the PG of $\mathrm{C} 3 \mathrm{H} / \mathrm{HeN}$ mice at as early as 6 hours after the endotoxin injection; and the level became minimal at 24 hours (Figure 1, A and $\mathrm{B}$ ). On the other hand, in the SMG, only a slight decrease in the AQP5 mRNA level was seen by RT-PCR at 24 hours after LPS injection (Figure 1A), and an approx. 50\% reduction was detected by real-time RT-PCR (Figure 1C). This LPS effect of reducing AQP5 and AQP1 mRNA levels in salivary glands would be mainly mediated via TLR4, because such changes were least in $\mathrm{C} 3 \mathrm{H} / \mathrm{HeJ}$ mice (Figure 1, A, D, and E), which mice are known to have a defective TLR4 as a result of a point mutation at nucleotide number 712 leading to replacement of a proline with a histidine. ${ }^{29}$ Similar, results were obtained in TLR4-knockout mice, C57BL/6 TLR4 ${ }^{-1-}$, and wild-type, C57BL/6 TLR4 ${ }^{+/+}$mice by real-time RT-PCR (Figure 1, F and G).

We next examined the effects of LPS on the protein levels of AQP5 and AQP1. The total membrane fractions were analyzed by immunoblotting with anti-AQP5 and anti-AQP1 antisera. A 27-kDa band was observed by immunoblotting with the anti-AQP5 antiserum, whereas $28-\mathrm{kDa}$ (non-glycosylated) and 35-40-kDa (glycosylated) bands were detected by anti-AQP1 antiserum in the PG and SMG samples from both $\mathrm{C} 3 \mathrm{H} / \mathrm{HeN}$ and $\mathrm{C} 3 \mathrm{H} /$ HeJ mice (Figure 2, A-C). The specificity of these reactions was confirmed by control experiments in which peptide-preabsorbed antisera were used (Figure 2C). The AQP5 protein level in the $\mathrm{PG}$ of $\mathrm{C} 3 \mathrm{H} / \mathrm{HeN}$ mice was decreased as early as 6 hours post injection; more dramatically, this level became almost undetectable at 24 hours (Figure 2A). Similar to the effect on water-channel
mRNAs, LPS induced a little down-regulation of AQP5 and AQP1 proteins in the $\mathrm{C} 3 \mathrm{H} / \mathrm{HeJ}$ mice. The response of the SMG to LPS was different from that of the PG; ie, the level of AQP1 protein did not change in the SMG of either $\mathrm{C} 3 \mathrm{H} / \mathrm{HeN}$ or $\mathrm{C} 3 \mathrm{H} / \mathrm{HeJ}$ mice, although the AQP5 level decreased in the former but not in the latter mice (Figure 2, $A$ and $B$ ). The reduction of AQP5 protein in the PG was also obvious by immunohistochemistry; ie, AQP5 protein expressed in the apical, lateral, and basal aspect of the plasma membrane of the acinar cells was appreciably decreased after LPS injection (Figure 2D).

Because LPS induced a prominent decrease in AQP5 protein levels, the rate of salivary secretion was measured to confirm the relevance of the AQP5 reduction to the physiological function (Figure 3, A-F). The whole saliva was collected immediately after pilocarpine injection. The whole saliva contains the secretions from the SMG, PG, and sublingual gland, all of which tissues express AQP5 in their acini. ${ }^{11}$ As shown in the Figure 3, $\mathrm{A}-\mathrm{F}$, in LPS-treated $\mathrm{C} 3 \mathrm{H} / \mathrm{HeJ}$ and C57BL/6 (TLR4 ${ }^{-1-}$ ) mice, the rate of salivation was almost the same as that by nontreated mice during 0 to 20 minutes after pilocarpine injection. However, a marked reduction in the salivation rate was observed in the $\mathrm{C} 3 \mathrm{H} / \mathrm{HeN}$ and C57BL/6 $\left(\mathrm{TLR}^{+/+}\right)$mice treated with LPS, indicating a strong correlation between physiological function and AQP5 levels as well as effects of LPS.

To determine whether the LPS induces any other gene expression changes, the production of nitric oxide $\left(\mathrm{NO}_{2}\right)$ in the serum were determined. As shown in the Figure 3 , $\mathrm{G}$ and $\mathrm{H}$, the production of $\mathrm{NO}_{2}{ }^{-}$plus $\mathrm{NO}_{3}{ }^{-}$was increased to 4- to 400-fold after LPS injection in the C57BL/6 $\left(\mathrm{TLR}^{+/+}\right)$and $\mathrm{C} 3 \mathrm{H} / \mathrm{HeN}$ mice; however, these 
A

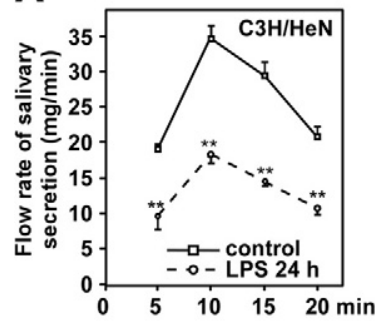

D

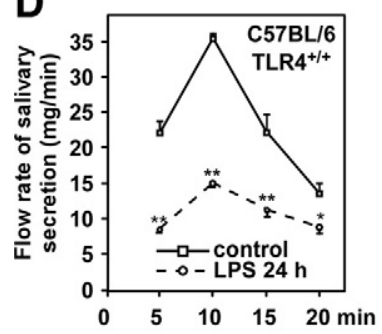

\section{E}

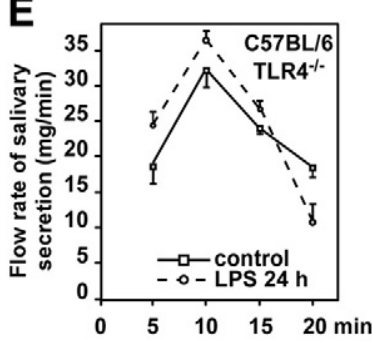

C
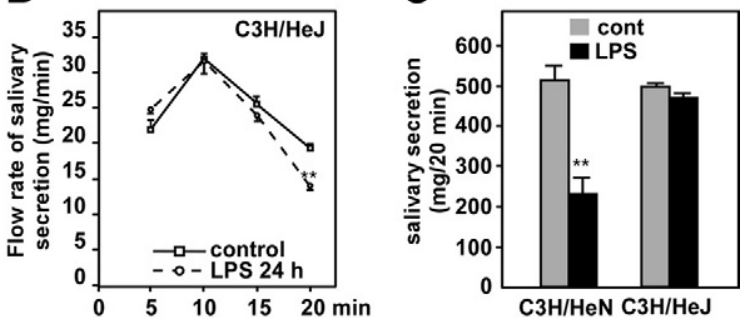

$\mathbf{F}$

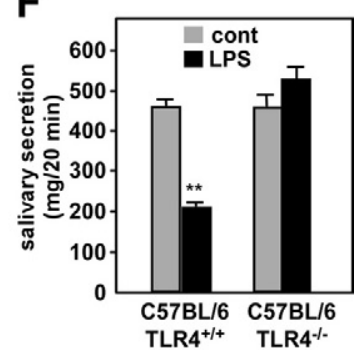

Figure 3. Effects of LPS on salivary secretion and production of serum $\mathrm{NO}_{2}{ }^{-} / \mathrm{NO}_{3}{ }^{-}$in $\mathrm{C} 3 \mathrm{H} /$

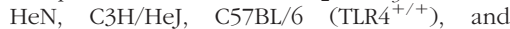
C57BL/6 (TLR4 ${ }^{-1-}$ ) mice. A-F: Pilocarpine-provoked salivary secretion. Solid line indicates control (non LPS-treated group); dashed line, LPS-treated group. Upper graphs, $\mathrm{C} 3 \mathrm{H} / \mathrm{HeN}$ and $\mathrm{C} 3 \mathrm{H} / \mathrm{HeJ}$ mice; lower graphs, C57BL/6 $\left(\right.$ TLR $^{+/+}$) and C57BL/6 (TLR4 ${ }^{-/-}$) mice. A, B, $\mathbf{D}$, and $\mathbf{E}$ : Time course of salivary secretion. $\mathbf{C}$ and F: Total salivary secretion $(0-20$ minutes after LPS treatment); $\mathbf{A}-\mathbf{C}$ : $\mathrm{C} 3 \mathrm{H} / \mathrm{HeN}$ and $\mathrm{C} 3 \mathrm{H} /$ HeJ mice. D-F: C57BL/6 $\quad\left(\right.$ TLR $^{+/+}$) and C57BL/6 (TLR4 ${ }^{-/-}$) mice. $\mathbf{G}$ and $\mathbf{H}$ : Serum $\mathrm{NO}_{2}{ }^{-}$ and $\mathrm{NO}_{2}{ }^{-}$plus $\mathrm{NO}_{3}{ }^{-}$levels in $\mathrm{C} 3 \mathrm{H} / \mathrm{HeN}, \mathrm{C} 3 \mathrm{H} /$ $\mathrm{HeJ}, \quad \mathrm{C} 57 \mathrm{BL} / 6 \quad\left(\mathrm{TLR}^{+/+}\right)$, and $\mathrm{C} 57 \mathrm{BL} / 6$ $\left(\right.$ TLR $4^{-1-}$ ) mice before and after LPS injection. G: $\mathrm{NO}_{2}{ }^{-}$levels. $\mathbf{H}$ : Levels of $\mathrm{NO}_{2}{ }^{-}$plus $\mathrm{NO}_{3}{ }^{-}$ Data are presented as the mean \pm SE of 4 mice ${ }^{*} P<0.05$ and ${ }^{* *} P<0.01$, significantly different from control at the same time points.

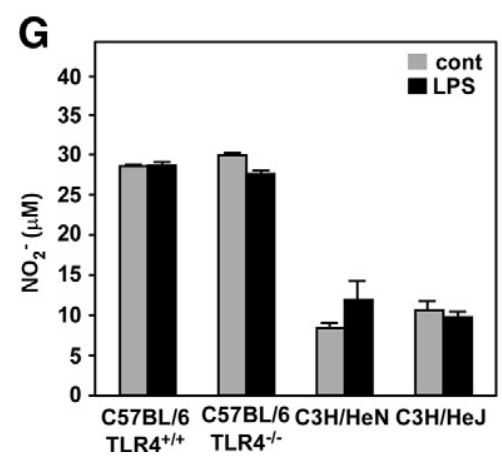

H

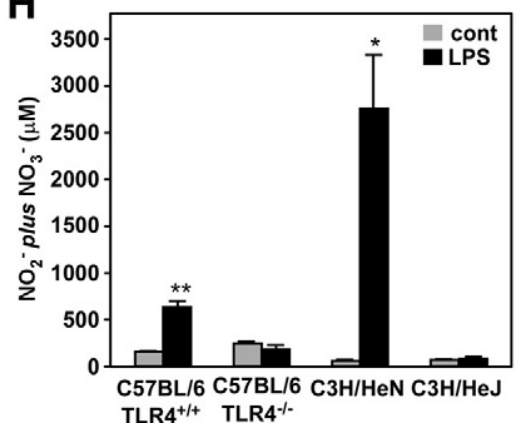

levels were almost same between LPS-treated and nontreated $\mathrm{C} 3 \mathrm{H} / \mathrm{HeJ}$ or $\mathrm{C} 57 \mathrm{BL} / 6$ (TLR4 $^{-/-}$) mice.

\section{LPS-Induced Down-Regulation of AQP5 and $A Q P 1$ in the $P G$ in Vitro}

A variety of LPS-signaling pathways have been elucidated previously. ${ }^{14}$ The best described pathway among them is the one via TLR4. The expression of TLR4 in the SMG and PG of $\mathrm{C} 3 \mathrm{H} / \mathrm{HeN}$ mice was detected by RT-PCR and Western blotting (Figure 4, A and B). Together with data shown in the previous section these findings suggest that i.p. injection of LPS provoked the down-regulation of the expression of both the mRNA and protein of AQP5 and AQP1 mainly via TLR4 in the PG. For the purpose of confirming these biochemical data, we examined the LPS signaling that provoked down-regulation of AQP5 and AQP1 in the PG in vitro. In the cultured PG, not only AQP5 but also AQP1 mRNA expression was markedly decreased in time- and dose-related manners after the LPS challenge (Figure 4, C and D). These results indicate that changes in AQP5 and AQP1 mRNA levels elicited by LPS were provoked by the direct action of the endotoxin on the PG and that such a tissue culture system is useful for detailed study of LPS-induced downregulation of AQPS.
Effects of NF- $\kappa B$ and MAPK Inhibitors on LPS-Induced Down-Regulation of AQP5 and AQP1 mRNAs

One of the major pathways of LPS/TLR4 signaling includes NF- $\kappa \mathrm{B}$ activation. To determine whether NF- $\kappa \mathrm{B}$ mediates LPS-induced down-regulation of AQP5 or AQP1 mRNA expression, we used 2 inhibitors of NF- $\mathrm{B}$ activation (ie, PDTC and MG132). The former is an inhibitor of $I_{\kappa} \mathrm{B}$ phosphorylation, and the latter, an inhibitor of proteasome responsible for $\mid \kappa \mathrm{B}$ degradation. These 2 inhibitors are commonly used to block the NF- $\kappa \mathrm{B}$ pathway by different mechanisms. The PG explants were preincubated in the presence or absence of PDTC or MG132 for 1 hour. The explants were then stimulated with LPS for 6 hours without removing the inhibitors. The LPSinduced decrease in AQP5 mRNA was strongly blocked by both PDTC and MG132, indicating the involvement of the NF- $\kappa$ B pathway in LPS-induced down-regulation of AQP5 in the PG. However, the AQP1 decrease by LPS was not blocked by PDTC or MG132 in the same samples used for the AQP5 experiment (Figure 5, A-C), suggesting irrelevance of the NF- $\kappa$ B pathway in AQP1 downregulation in this tissue. The activity of p65 and p50 to be translocated to the nucleus was detected by immunohistochemistory (Figure 5, E and F). The LPS-induced nu- 
A

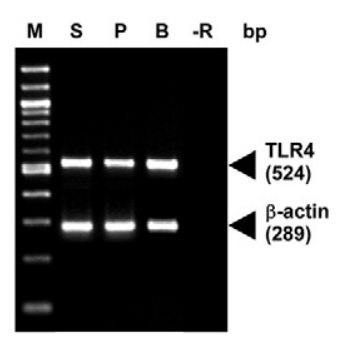

C

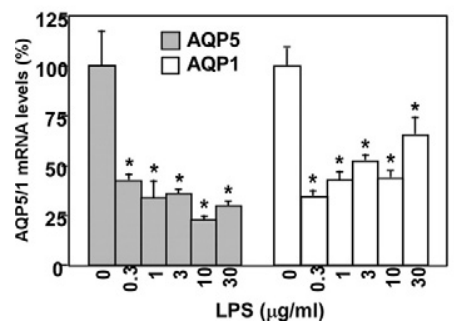

B

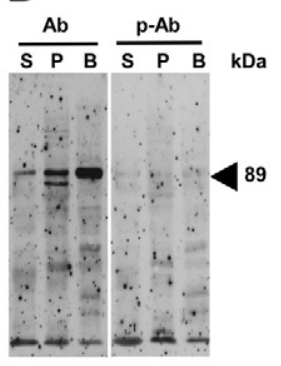

D

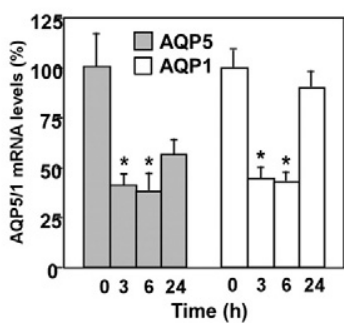

Figure 4. Expression of TLR4 mRNA and protein in the PG and downregulation of PG AQP5 and AQP1 by LPS in vitro. A, Analysis of the TLR4 mRNA by RT-PCR. M indicates marker (100 bp DNA Ladder); S, SMG; P, PG; $\mathrm{B}$, bladder; $-\mathrm{R}$, no added RNA. B: Western blotting of cytosolic proteins to detect TLR4. Ab indicates anti-TLR4 polyclonal antibody; $\mathrm{p}-\mathrm{Ab}$, peptidepreabsorbed anti-TLR4 polyclonal antibody. S, P, and B, SMG, PG, and bladder, respectively. C and D: Real-time RT-PCR analysis of the AQP5 and AQP1 mRNAs in the PG tissues cultured in vitro in the presence and absence of LPS. C: Dose-response curve. The PG tissues were cultured in the presence of the indicated amounts of LPS for 6 hours. D: Time course. The PG tissues were cultured in the presence of $1 \mu \mathrm{g} / \mathrm{ml}$ LPS for the time indicated. ${ }^{*} P<0.05$, significantly different from the control $(0)$.

clear translocation of p65 or p50 (nuclear staining) was blocked by not only PDTC but also MG132.

Similarly, treatment of tissue explants with tyrphostin AG126, an inhibitor of ERK1/2, ${ }^{30}$ or with SP600125, a specific inhibitor for JNK, ${ }^{31}$ strongly suppressed the LPSinduced decrease in AQP5 mRNA (Figure 5, A and B). Also, the 2 inhibitors actually inhibited $\mathrm{p}$-ERK $1 / 2$ and JNK activities, respectively as shown in Figure 5D. These results clearly demonstrate that these 2 pathways were actually involved in LPS-induced down-regulation of AQP5 mRNA. On the other hand, SB203580, a specific inhibitor of p38 MAPK, ${ }^{32}$ only partially suppressed the LPS-induced decrease in AQP5 mRNA. Also, the LPSinduced decrease in AQP1 was suppressed only by SP600125, and it was suppressed neither by tyrphostin AG126 nor by SB203580. The present data suggest the possibility that MAPK pathways (ERK1/2 and JNK) were involved in LPS-induced down-regulation of AQP5 but only JNK, in the AQP1 down-regulation.

As just described, AQP1 down-regulation was suppressed only by SP600125 and was not suppressed by tyrphostin AG126 nor by SB203580. Also, the two inhibitors for NF- $\kappa$ B did not block the LPS-induced downregulation of $A Q P 1$, probably because no NF- $\kappa$ B-binding element is found at the promoter of the AQP1 gene by computer analysis of available databases (GenBank/ NCBI Data Bank; accession number, MMU 67925). We assume that only the JNK pathway was involved in AQP1 down-regulation much less efficiently than in AQP5 down-regulation. For the regulation of AQP5 transcrip-

tion, AG126 or SP600125 completely suppressed the LPS-induced down-regulation, whereas SB203580 only partially did so, suggesting the strong possibility of the involvement of c-Fos and C-Jun, but less possibility, if any, of the involvement of CREB transcription factor in the AQP5 down-regulation. Therefore, it is very probable that $\mathrm{c}-\mathrm{Fos} / \mathrm{p}-\mathrm{c}-\mathrm{Jun}$ in addition to NF- $\kappa \mathrm{B}$ was involved in the LPS-induced down-regulation of AQP5.

Thus in the next experiment we analyzed the existence and/or induction of transcription factors NF- $\kappa \mathrm{B}$ and C-Jun/ c-Fos in the PG of $\mathrm{C} 3 \mathrm{H} / \mathrm{HeN}$ mice.

\section{LPS-Induced NF- $\kappa B$ DNA-Binding Activity}

By Western blotting, we examined the expression of p65, a subunit of $\mathrm{NF}-\kappa \mathrm{B}$, in the $\mathrm{PG}$ of normal $\mathrm{C} 3 \mathrm{H} / \mathrm{HeN}$ mice (Figure 6A). As shown in Figure 6A, a band with an apparent MW of $65-\mathrm{kDa}$ was detected in the PG, which specificity was confirmed by preabsorption of the antibody with the blocking peptide. To evaluate possible changes in the DNA-binding activity of putative $P G$ $\mathrm{NF}-\kappa \mathrm{B}$ to the AQP5 promoter in response to LPS, we performed an EMSA using 2 DIG-labeled NF- $\kappa$ B DNAbinding sequences (probe 1 and probe 2; see Materials and Methods section) of the AQP5 promoter. The results showed that the DNA-binding activity of the PG nuclear extract toward the NF- $\kappa \mathrm{B}$-responsive element of the AQP5 promoter increased at 1 hour after LPS injection (Figure 6B). This activity was decreased by the presence of cold probe and/or anti-p65 antibody, suggesting the specificity of the reaction. The existence of p65 in nuclei of $P G$ acini was confirmed by double immunostaining for AQP5 and p65 (Figure 6C).

\section{LPS-Induced AP-1/C-Fos/c-Jun DNA-Binding and $A P-1 / C R E B$-Binding Activities in the $P G$}

Similarly, EMSA was also performed by using DIG-labeled AP-1/C-Fos/c-Jun and AP-1/CREB DNA binding sequences (5'-GTCTAGTGTGACTAAAGTGATGGA-3' and 5'AGAAACGAAGAGTCAGAGAGACAG-3', respectively) as probes because these consensus sequences were found in the AQP5 promoter. The result indicated that these sequences did not show a distinct different electrophoretic pattern between the PG proteins before and after LPS stimulation (data not shown); suggesting the protein induced by LPS did not directly bind to these elements.

\section{Detection of LPS-Induced Changes in p-c-Jun and c-Fos Protein Levels in the PG}

Although EMSA by using AP-1/C-Fos/C-Jun binding sequences of the AQP5 promoter did not detect any binding protein in the $P G$ extract, we next examined to detect the changes in the p-c-Jun and c-Fos levels in the PG tissue, because $\mathrm{p}$-c-Jun and c-Fos are thought to play central roles in inflammatory responses among the AP-1 family proteins. As shown in Figure 7A, the antibody 
A

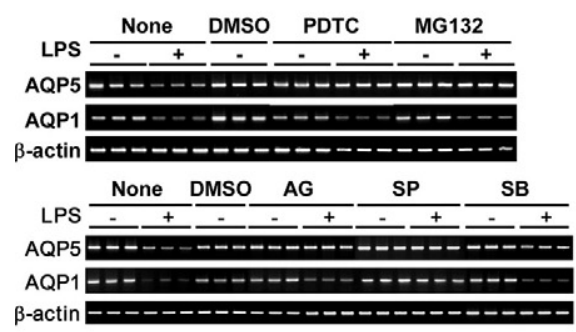

D

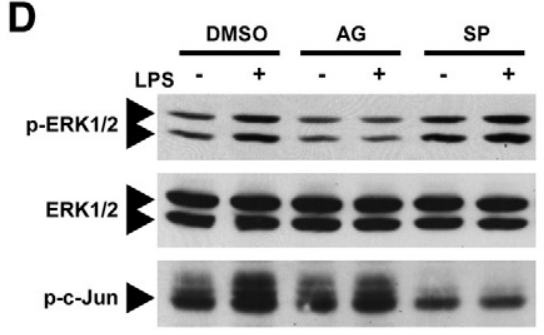

B

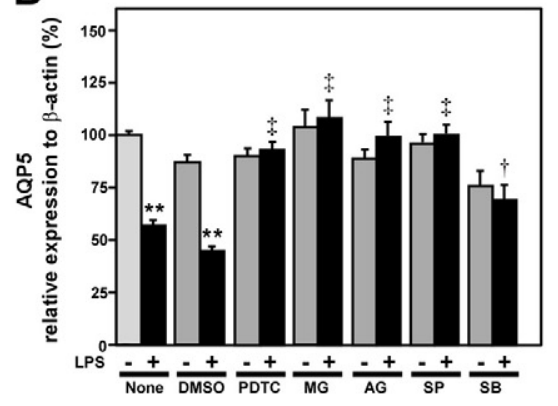

E

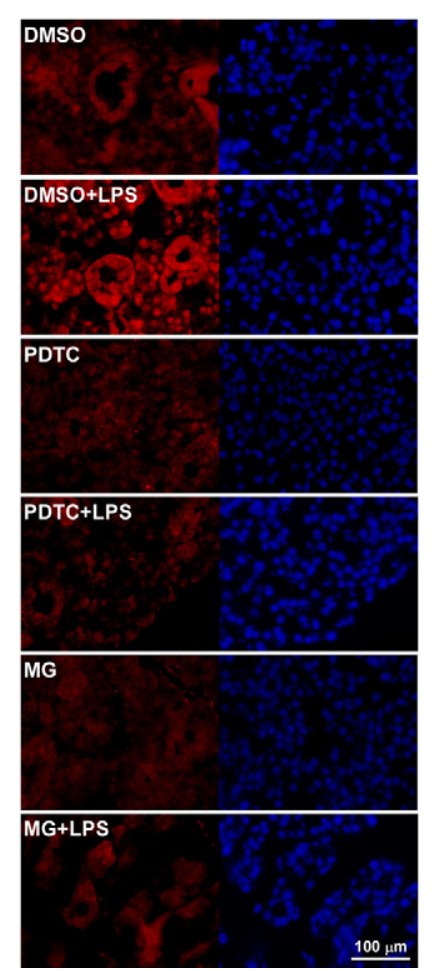

C

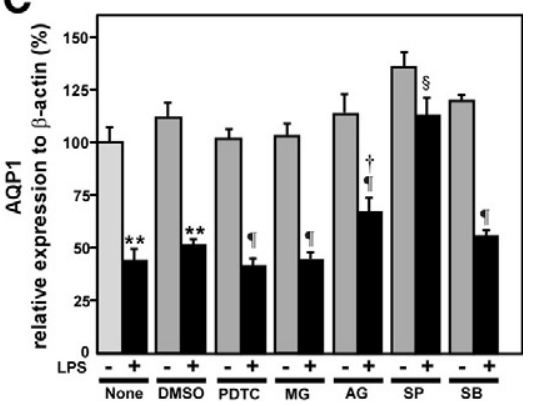

$\mathbf{F}$
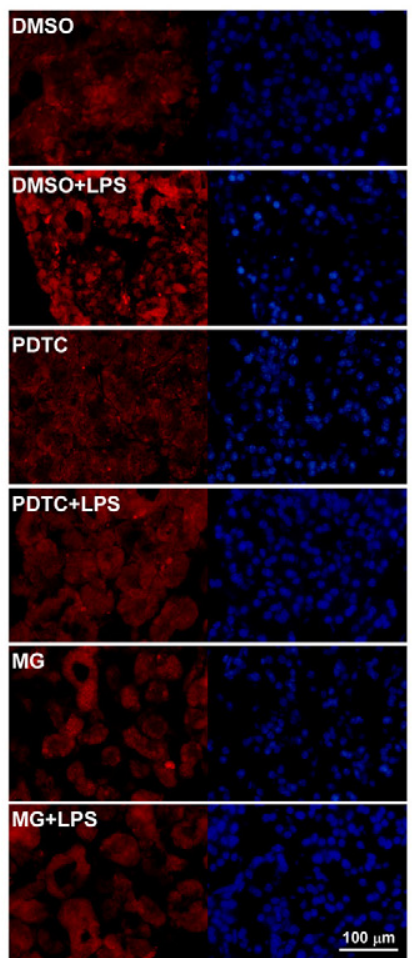

preabsorption experiment clearly showed the presence of 39-kDa p-c-Jun and 55-kDa c-Fos in the PG, which molecular weights agreed well with values reported for them. ${ }^{33}$ Western blotting revealed that $\mathrm{p}$-c-Jun and c-Fos levels in the PG were significantly increased by LPS in a time-dependent manner (Figure 7B). Also, immunohistochemistry of $\mathrm{p}$-c-Jun indicated the localization of this transcription factor in the nuclei of PG acinar cells, which were distinguished from duct cells by the presence of AQP5 (Figure 7C).

\section{Possible Formation of a Complex of NF- $\kappa B$, p-c-Jun, and c-Fos}

By in vitro tissue culture experiments, blocking of the $\mathrm{NF}-\kappa \mathrm{B}, \mathrm{p}-\mathrm{c}-J$ un, or c-Fos pathway completely suppressed the down-regulating effect of LPS on AQP5 mRNA (Figure 5), implying that all three of these transcription factors were indispensable for this mechanism. Thus, the possibility that the three transcription factors form a complex was tested by conducting a coimmuno- precipitation experiment using Sepharose coupled with anti-NF- $\kappa$ B, anti-p-C-Jun, and anti-c-Fos antibodies (Figure 7D). The assessment of the eluates from these antibody Sepharose columns, which had been loaded and incubated with a PG extract from an LPS-stimulated mouse (3 hours), showed that p-c-Jun was bound specifically to all of these antibody Sepharose columns, suggesting the formation of a complex of the three transcription factors. On the other hand, when the PG extract from nontreated mice was applied, eluate from the anti-NF- $\kappa \mathrm{B}$ column did not contain any detectable amount of $\mathrm{p}-\mathrm{c}$ Jun. Although the present Western blotting detected p-cJun in the eluate from anti-p-c-Jun column and anti-c-Fos column, their levels were, again, much less than those shown in samples from LPS-injected mice. These experiments imply that basal level of the p-c-Jun/c-Fos complex was present in the PG of non-treated mice.

As described previously, our in vivo experiments showed that the response of SMG AQP5 to LPS was less than that of PG AQP5 (Figures 1 and 2). On the other hand, from the data shown above, NF- $\kappa \mathrm{B}$ is supposed to 
A
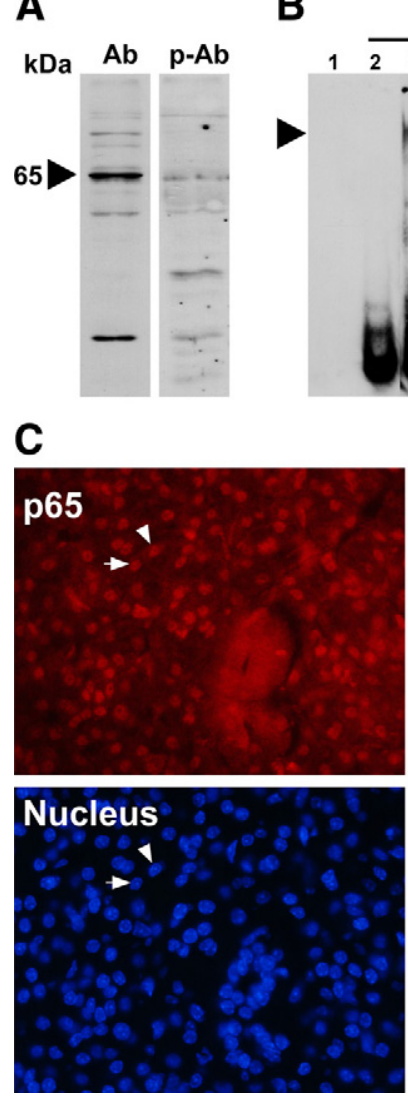

probe1
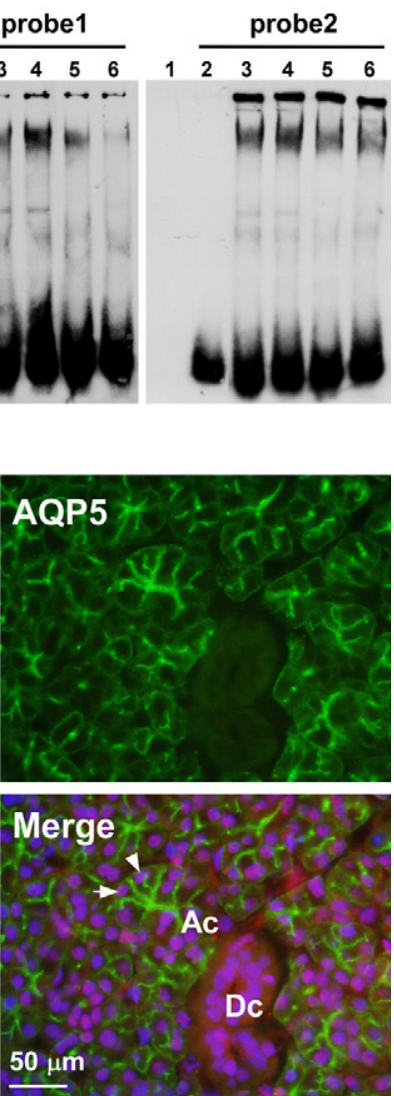

Figure 6. Analysis of NF- $\kappa \mathrm{B}$ in the PG. A: Western blotting of the NF- $\kappa \mathrm{B}$ protein in a PG nuclear extract from a $\mathrm{C} 3 \mathrm{H} / \mathrm{HeN}$ mouse injected with LPS 1 hour before sacrifice. Ab indicates anti-p65 polyclonal antibody; $\mathrm{p}-\mathrm{Ab}$, peptide-preabsorbed anti-p65 polyclonal antibody. B: EMSA of NF- $\kappa \mathrm{B}$ in the PG from nontreated and LPS-injected C3H/HeN mice. probe1, 5'-AGTCTCAGGCACTTCCCTAAGCC-3'; probe 2, 5'-ACTCCCGATCCACTCCCCCGCTCC-3' Lane 1, no probe and no protein sample; lanes 2-6, experiments in the presence of probe; lane 2, no protein sample; lane 3, nuclear extract from nontreated $\mathrm{C} 3 \mathrm{H} / \mathrm{HeN}$ mice; lane $\mathbf{4}$, nuclear extract from LPS-injected $\mathrm{C} 3 \mathrm{H}$ / $\mathrm{HeN}$ mice; lane 5, nuclear extract from the LPS-injected $\mathrm{C} 3 \mathrm{H} / \mathrm{HeN}$ mice preincubated with 50 -fold molar excess of unlabeled double-stranded oligonucleotide of NF- $\kappa \mathrm{B}$ specific probe; lane $\mathbf{6}$, nuclear extract from an LPSinjected $\mathrm{C} 3 \mathrm{H} / \mathrm{HeN}$ mouse, with extract preincubated with antibody against p65. An arrowhead indicates the shifted double strand DNA probes. C: Immunohistochemical detection of $\mathrm{p} 65$ and AQP5 in the PG of a C3H/HeN mouse that had been injected with LPS 1 hour before sacrifice. Subcellular localization of p 65 protein by Alexa Fluor 594 (red, upper left), subcellular localization of AQP5 by FITC immunofluorescence (green, upper right), cell nuclei stained by DAPI (blue, lower left), and a merged picture (lower right) are shown. Ac indicates an acinus; Dc, a duct. Arrowheads indicate typical nuclei of acinar cells showing exact localization of p65 in the nucleus.

play a crucial role in LPS-induced potential down-regulation of AQP5 in the PG. To pursue the cause of such a poor response of SMG AQP5 to LPS, we examined the expression of p65 in the SMG by Western blotting and immunohistochemistry. By Western blotting, different from the p65 level found in the cytosolic proteins and nuclear extracts of the $P G$, the expression of this protein in SMG was very low (ie, p65 was not detectable in either the cytosolic protein fraction nor nuclear extract of the SMG in both non-treated and LPS-treated $\mathrm{C} 3 \mathrm{H} / \mathrm{HeN}$ mice; data not shown). Similarly, by immunohistochemistry, p65 was not detected in acinar and duct cells of the SMG, although the expression levels of $\mathrm{p}$-c-Jun and $\mathrm{C}$-Fos in the SMG were comparable with those in the PG (data not shown). These data imply that the

A
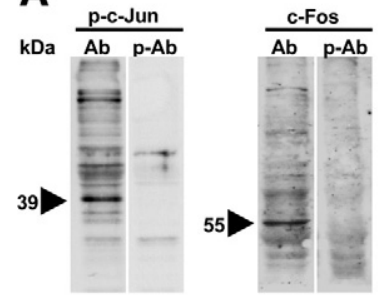

B

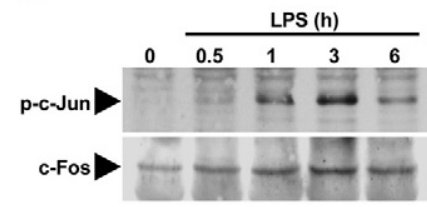

C
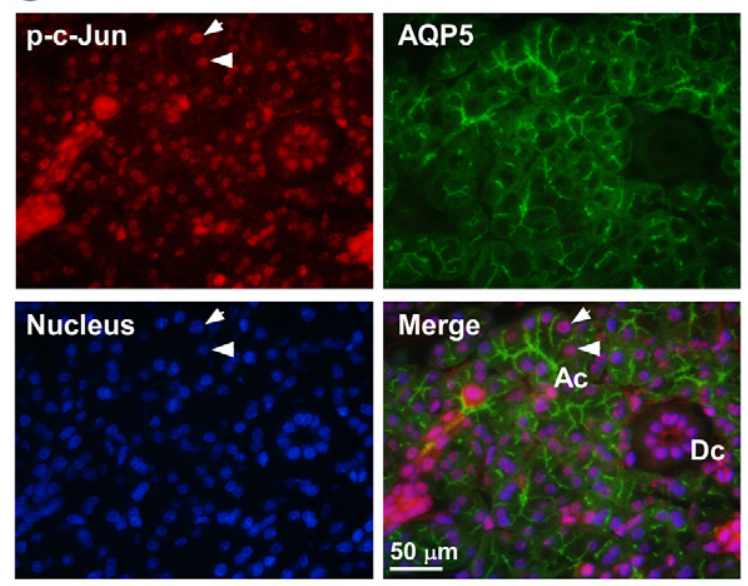

D LPS $(3 h)$
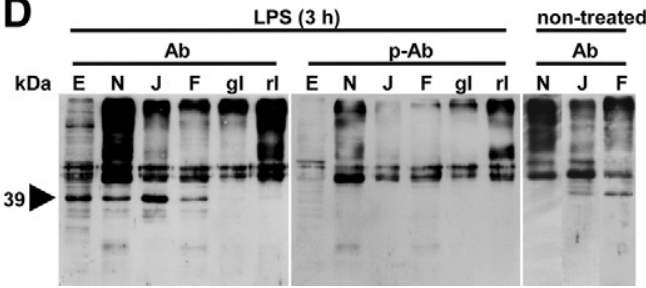

Figure 7. Analysis of p-c-Jun and c-Fos in the PG. A: Control experiment using the cytosolic proteins of the PG from $\mathrm{C} 3 \mathrm{H} / \mathrm{HeN}$ mice injected with LPS 1 hour before sacrifice. Ab indicates anti-p-c-Jun (left) and anti-c-Fos (right) p-Ab, peptide-preabsorbed p-c-Jun antibody (left) and peptide-preabsorbed c-Fos antibody (right). B: Time course of expression of p-c-Jun and c-Fos proteins in the PG of LPS-injected $\mathrm{C} 3 \mathrm{H} / \mathrm{HeN}$ mice, as detected by Western blotting. C: Immunohistochemical detection of AQP5 and p-c-Jun in the PG of $\mathrm{C} 3 \mathrm{H} / \mathrm{HeN}$ mice injected with LPS 1 hour before sacrifice. Pictures show subcellular localization of p-c-Jun by Alexa Fluor 594 (red, upper left), subcellular localization of AQP5 by FITC immunofluorescence (green, upper right), cell nuclei stained by DAPI (blue, lower left), and a merged picture (lower right) are shown. Ac indicates an acinus; Dc, a duct. Arrowheads indicate typical nuclei of acinar cells showing exact localization of p-c-Jun in the nucleus. D: Association of p-c-Jun with NF- $\kappa$ B subunit p 65 and c-Fos. Eluates from various antibody columns were subjected to Western blotting. Ab indicates anti-p-c-Jun polyclonal antibody; $\mathrm{p}$-Ab, peptide-preabsorbed anti-p-c-Jun polyclonal antibody. E: PG nuclear extract prepared from LPS-injected $\mathrm{C} 3 \mathrm{H} / \mathrm{HeN}$ mouse $(15 \mu \mathrm{g})$. N, J, F, gI, and rI, eluates from antibody columns or normal IgG columns. N, rabbit anti-p65 column; J, rabbit anti-p-c-Jun column; F, goat anti-c-Fos column; gI, normal goat IgG column; rI, normal rabbit IgG column. A $0.25-\mathrm{mg}$ aliquot of the PG nuclear extract was applied to the anti-p-c-Jun column, and 1-mg extracts to the other columns.

poor response of SMG AQP5 to LPS would be, at least in part, due to lower expression of p65 in the SMG than that in the PG.

\section{Discussion}

We found that LPS down-regulated AQP5 and AQP1 mRNA expression in one of the salivary glands, $P G$, both 
in vivo and in vitro. Such an LPS effect was largely mediated by TLR4, because this endotoxin only poorly affected the mRNA/protein level for AQP5 and AQP1 in $\mathrm{C} 3 \mathrm{H} / \mathrm{HeJ}$ mice, a TLR4-mutant strain. The LPS effect of down-regulating $A Q P 5$ and $A Q P 1$ mRNA expression may be attributed to the direct action of this endotoxin on the PG, because PG strongly expressed TLR4 and the endotoxin effects were also observed in an in vitro tissue culture system.

One of the major pathways provoked by LPS is the one leading to NF- $\kappa \mathrm{B}$ activation via TLR4. The NF- $\kappa \mathrm{B}$ transcription factor is known to be activated in response to inflammation. Here we found that the NF- $\kappa$ B pathway was involved in the LPS-induced down-regulation of AQP5 but not AQP1, because two inhibitors of NF- $\kappa \mathrm{B}, \mathrm{PDTC}$ and MG132, blocked the down-regulation of AQP5 but not AQP1 mRNA after the endotoxin stimulation in the in vitro experiments. These data were supported by the fact that two consensus sequences for the NF- $\kappa \mathrm{B}$ binding site were found in the $5^{\prime}$-flanking region of the AQP5 gene, ${ }^{34}$ whereas no such binding site was found in the promoter region of the AQP1 gene. TNF- $\alpha$ is known to decrease the expression of AQP5 mRNA and protein in MLE-12 cells, in which activation of TNF- $\alpha$ receptor- 1 and NF- $\kappa$ B signaling are involved. ${ }^{35}$ Using the specific NF- $\kappa \mathrm{B}$-binding sequences, we showed that the AQP5 promoter could bind this transcription factor and that the binding was increased by LPS. In addition, the expression of NF- $\kappa \mathrm{B}$ in the PG was increased, and it was localized in nuclei of acinar cells in PG from LPS-stimulated mice. Taken together, our findings suggest that the activation of NF- $\kappa \mathrm{B}$ is indispensable for AQP5 down-regulation by LPS.

The above data prompted us to investigate whether any other pathway in the LPS signaling is involved in AQP5 and AQP1 regulation. TLR4 stimulation is known to trigger the MAPK pathway, resulting in the activation of kinases, such as ERK1/2, JNK, and p38 MAPK. ${ }^{36,37}$ It has been shown also that p38 MAPK mediates the translocation of CD14, a membrane transporter protein ${ }^{38,39}$ associated with TLR4, whereas JNK activation is important for LPS-induced expression of MCP-1 (monocyte chemoattractant protein)..$^{40}$ Besides ERK $1 / 2$ and JNK have been shown to play pivotal roles in LPS-induced acute lung injury. ${ }^{41}$ Tyrphostin AG126 and SP600125, commonly used to inhibit ERK $1 / 2$ and JNK, respectively, completely blocked the down-regulation of AQP5 mRNA by LPS. Also, the LPS-induced decrease in the AQP5 mRNA was partially blocked by SB203580, an inhibitor of p38 MAPK. These results suggest that the MAPK pathway was involved in the LPS-induced down-regulation of AQP5 mRNA. However, only JNK signaling pathways was implied to be involved in the down-regulation of AQP1. Because the consensus sequences for an AP-1/C-Jun/CFos binding site is present in the $5^{\prime}$-flanking region of the AQP5 gene, ${ }^{34}$ we tested the DNA-binding of the PG nuclear extract to this sequence. No appreciable binding was detected by EMSA, though p-c-Jun and c-Fos were induced by LPS in the PG.

Our inhibitor experiments showed that the activation of both NF- $\kappa$ B and c-Jun/c-Fos was indispensable for AQP5 down-regulation by LPS and that only NF- $\kappa B$ DNA-binding activity was increased in the LPS-induced PG. It has been reported by Stein et al that cross-coupling of C-Jun or c-Fos with the NF- $\kappa$ B subunit p65 through the Rel homology domain leads to a synergized potentiation of both $\mathrm{AP}-1$ and NF- $\kappa \mathrm{B}$ transactivation. ${ }^{42}$ More recently, Shyu et al visualized AP-1-NF- $\kappa$ B ternary complex formation in activated T cells. ${ }^{43}$ In asthma, therefore, elevation of both AP-1 and NF- $\kappa$ B may lead to far greater inflammation than would have been present if either transcription factor alone had been activated. ${ }^{44}$ In fact, by an immunoprecipitation experiment using an extract of an LPS-stimulated mouse PG, we detected the binding of p-c-Jun to the anti-c-Fos and anti-p65 columns, implying that these three proteins were associated with each other. Further, p65, p-c-Jun, and AQP5 were colocalized in the acinar cells in the PG after LPS injection. Thus, it is probable that p-c-Jun and c-Fos induced by MAPK pathways after LPS stimulation interact with NF- $\kappa \mathrm{B}$ p65 resulting in acute down-regulation of AQP5 mRNA in the PG via cross-coupling.

In the present study, the amount of the AQP5 protein in the plasma membrane and the mRNA expression level were decreased after LPS injection. This decrease at 24 hours would be likely, because AQP5 and AQP1 expression in the lung of FVB/N wild-type mice is reported to be decreased after an adenoviral infection. ${ }^{23}$ Down-regulation of AQP5 and AQP1 was only weakly seen in $\mathrm{C} 3 \mathrm{H} / \mathrm{HeJ}$ mice, a TLR4-mutant strain, and the expression of TLR4 in the salivary gland was confirmed in the present study, which well agrees with the recent report by Nishimura et al. ${ }^{19}$ By binding to the TLR4, LPS is known to up-regulate various inflammatory mediators and proteins, such as interleukin-6 and COX-2. ${ }^{37,45}$ On the contrary, recent data revealed that LPS is also involved in down-regulation responses. For example, LPS suppresses ApoE gene (human apolipoprotein E) in macrophages. ${ }^{36}$ Baranova et al have reported that LPS is able to down-regulate both mRNA and protein of the scavenger receptor B1 and ATP-binding cassette A1 in a macrophage cell line, RAW cells. ${ }^{46}$ Here we demonstrated that LPS down-regulated the expression of AQP5, an important water channel in the salivary gland. The physiological significance of such down-regulation is still unclear. However, because saliva secretion is strongly affected by the AQP5 protein level $(10,11$, and this study), we hypothesize that AQP5 downregulation, resulting in reduced saliva secretion, may facilitate keeping a high body temperature (fever), which is induced by LPS on its direct interaction with the hypothalamus. This would be advantageous for the defense system of host animals.

There are no previous reports describing the effect of endotoxin on the acute responses of salivary gland AQPS in humans or animals. Here, we have provided the first evidence that LPS induces down-regulation of AQP5 mRNA in the PG. We suggest that the NF- $\kappa$ B transcription factor is directly involved in the AQP5 down-regulation and that cross-coupling with $\mathrm{p}$-c-Jun/c-Fos transcription factors facilitate potentiation of such regulation. 


\section{References}

1. Yakata K, Hiroaki Y, Ishibashi K, Sohara E, Sasaki S, Mitsuoka K, Fujiyoshi Y: Aquaporin-11 containing a divergent NPA motif has normal water channel activity. Biochim Biophys Acta 2007, 1768:688-693

2. Itoh A, Tsujikawa T, Fujiyama Y, Bamba T: Enhancement of aquaporin-3 by vasoactive intestinal polypeptide in a human colonic epithelial cell line. J Gastroenterol Hepatol 2003, 18:203-210

3. Verkman AS: Physiological importance of aquaporins: lessons from knockout mice. Curr Opin Nephrol Hypertens 2000, 9:517-522

4. Marinelli RA, Tietz PS, Pham LD, Rueckert L, Agre P, LaRusso NF: Secretin induces the apical insertion of aquaporin-1 water channels in rat cholangiocytes. Am J Physiol Gastrointest Liver Physiol 1999, 276:G280-G286

5. Steinfeld S, Cogan E, King LS, Agre P, Kiss R, Delporte C: Abnormal distribution of aquaporin-5 water channel protein in salivary glands from Sjögren's syndrome patients. Lab Invest 2001, 81:143-148

6. Tsubota K, Hirai S, King LS, Agre P, Ishida N: Defective cellular trafficking of lacrimal gland aquaporin-5 in Sjögren's syndrome. Lancet 2001, 357:688-689

7. Beitz E, Schultz JE: The mammalian aquaporin water channel family: a promising new drug target. Curr Med Chem 1999, 6:457-467

8. Francis P, Chung JJ, Yasui M, Berry V, Moore A, Wyatt MK, Wistow G, Bhattacharya SS, Agre P: Functional impairment of lens aquaporin in two families with dominantly inherited cataracts. Hum Mol Genet 2000, 9:2329-2334

9. Raina S, Preston GM, Guggino WB, Agre P: Molecular cloning and characterization of an aquaporin cDNA from salivary, lacrimal, and respiratory tissues. J Biol Chem 1995, 270:1908-1912

10. Murdiastuti K, Purwanti N, Karabasil MR, Li X, Yao C, Akamatsu T, Kanamori N, Hosoi K: A naturally occurring point mutation in the rat aquaporin 5 gene, influencing its protein production by and secretion of water from salivary glands. Am J Physiol Gastrointest Liver Physiol 2006, 291:G1081-G1088

11. Ma T, Song Y, Gillespie A, Carlson EJ, Epstein CJ, Verkman AS: Defective secretion of saliva in transgenic mice lacking aquaporin-5 water channels. J Biol Chem 1999, 274:20071-20074

12. Marples D, Frokiaer J, Nielsen S: Long-term regulation of aquaporins in the kidney. Am J Physiol Renal Physiol 1999, 276:F331-F339

13. Bai C, Fukuda N, Song Y, Ma T, Matthay MA, Verkman AS: Lung fluid transport in aquaporin-1 and aquaporin-4 knockout mice. J Clin Invest 1999, 103:555-561

14. Medzhitov R: Toll-like receptors and innate immunity. Nat Rev Immunol 2001, 1:135-145

15. Hallman M, Ramet M, Ezekowitz RA: Toll-like receptors as sensors of pathogens. Pediatr Res 2001, 50:315-321

16. Raetz CR: Biochemistry of endotoxins. Annu Rev Biochem 1990, 59:129-170

17. Haziot A, Chen S, Ferrero E, Low MG, Silber R, Goyert SM: The monocyte differentiation antigen. CD14, is anchored to the cell membrane by a phosphatidylinositol linkage. J Immunol 1988, 141:547-552

18. Goyert SM, Ferrero E, Rettig WJ, Yenamandra AK, Obata F, Le Beau MM: The CD14 monocyte differentiation antigen maps to a region encoding growth factors and receptors. Science 1988, 239:497-500

19. Nishimura M, Naito S: Tissue-specific mRNA expression profiles of human toll-like receptors and related genes. Biol Pharm Bull 2005 , 28:886-892

20. Uehara A, Sugawara S, Watanabe K, Echigo S, Sato M, Yamaguchi T, Takada $\mathrm{H}$ : Constitutive expression of a bacterial pattern recognition receptor, CD14, in human salivary glands and secretion as a soluble form in saliva. Clin Diagn Lab Immunol 2003, 10:286-292

21. Blumer KJ, Johnson GL: Diversity in function and regulation of MAP kinase pathways. Trends Biochem Sci 1994, 19:236-240

22. Deacon K, Blank JL: MEK kinase 3 directly activates MKK6 and MKK7, specific activators of the p38 and c-Jun NH2-terminal kinases. J Biol Chem 1999, 274:16604-16610

23. Towne JE, Harrod KS, Krane CM, Menon AG: Decreased expression of aquaporin (AQP)1 and AQP5 in mouse lung after acute viral infection. Am J Respir Cell Mol Biol 2000, 22:34-44

24. Yao C, Li X, Kwartarini M, Kosugi-Tanaka C, Akamatsu T, Kanamori N, Hosoi K: Lipopolysaccharide-induced elevation and secretion of interleukin-1beta in the submandibular gland of male mice. Immunology 2005, 116:213-222

25. Yao C, Karabasil MR, Purwanti N, Li X, Akamatsu T, Kanamori N,
Hosoi $\mathrm{K}$ : Tissue kallikrein $\mathrm{mK} 13$ is a candidate processing enzyme for the precursor of interleukin-1beta in the submandibular gland of mice. J Biol Chem 2006, 281:7968-7976

26. Topper RJ, Oka T, Vonderhaar BK: Techniques for studying development of normal mammary epithelial cells in organ culture. Methods Enzymol 1975, 39:443-454

27. Li X, Azlina A, Karabasil MR, Purwanti N, Hasegawa T, Yao C, Akamatsu T, Hosoi K: Degradation of submandibular gland AQP5 by parasympathetic denervation of chorda tympani and its recovery by cevimeline, an M3 muscarinic receptor agonist. Am J Physiol Gastrointest Liver Physiol 2008, 295:G112-G123

28. Chandrasekar B, Streitman JE, Colston JT, Freeman GL: Inhibition of nuclear factor kappa B attenuates proinflammatory cytokine and inducible nitric-oxide synthase expression in postischemic myocardium. Biochim Biophys Acta 1998, 1406:91-106

29. Poltorak A, He X, Smirnova I: Defective LPS signaling in $\mathrm{C} 3 \mathrm{H} / \mathrm{HeJ}$ and C57BL/10ScCr mice: mutations in TIr4 gene. Science 1998 282:2085-2088

30. Novogrodsky A, Vanichkin A, Patya M, Gazit A, Osherov N, Levitzki A: Prevention of lipopolysaccharide-induced lethal toxicity by tyrosine kinase inhibitors. Science 1994, 264:1319-1322

31. Gazel A, Banno T, Walsh R, Blumenberg M: Inhibition of JNK promotes differentiation of epidermal keratinocytes. J Biol Chem 2006 , 281:20530-20541

32. Wang XZ, Ron D: Stress-induced phosphorylation and activation of the transcription factor CHOP (GADD153) by p38 MAP Kinase. Science 1996, 272:1347-1349

33. Quan T, He T, Voorhees JJ, Fisher GJ: Ultraviolet irradiation induces Smad7 via induction of transcription factor AP-1 in human skin fibroblasts. J Biol Chem 2005, 280:8079-8085

34. Krane CM, Towne JE, Menon AG: Cloning and characterization of murine Aqp5: evidence for a conserved aquaporin gene cluster. Mamm Genome 1999, 10:498-505

35. Towne JE, Krane CM, Bachurski CJ, Menon AG: Tumor necrosis factor-alpha inhibits aquaporin 5 expression in mouse lung epithelial cells. J Biol Chem 2001, 276:18657-18664

36. Gafencu AV, Robciuc MR, Fuior E, Zannis VI, Kardassis D, Simionescu M: Inflammatory signaling pathways regulating ApoE gene expression in macrophages. J Biol Chem 2007, 282:21776-21785

37. Guha M, Mackman N: LPS induction of gene expression in human monocytes. Cell Signal 2001, 13:85-89

38. Kojima K, Musch MW, Ropeleski MJ, Boone DL, Ma A, Chang EB: Escherichia coli LPS induces heat shock protein 25 in intestinal epithelial cells through MAP kinase activation. Am J Physiol Gastrointest Liver Physiol 2004, 286:G645-G652

39. Shuto T, Xu H, Wang B, Han J, Kai H, Gu XX, Murphy TF, Lim DJ, Li JD: Activation of NF-kappa B by nontypeable Hemophilus influenzae is mediated by toll-like receptor 2-TAK1-dependent NIK-IKK alpha/ beta-I kappa B alpha and MKK3/6-p38 MAP kinase signaling pathways in epithelial cells. Proc Natl Acad Sci USA 2001, 98:8774-8779

40. Arndt PG, Suzuki N, Avdi NJ, Malcolm KC, Worthen GS: Lipopolysaccharide-induced c-Jun $\mathrm{NH}$ 2-terminal kinase activation in human neutrophils: role of phosphatidylinositol 3-Kinase and Syk-mediated pathways. J Biol Chem 2004, 279:10883-10891

41. Lee HS, Kim HJ, Moon CS, Chong YH, Kang JL: Inhibition of C-Jun $\mathrm{NH} 2$-terminal kinase or extracellular signal-regulated kinase improves lung injury. Respir Res 2004, 5:1-23

42. Stein B, Baldwin AS, Ballard DW, Greene WC, Angel P, Herrlich P: Cross-coupling of the NF-kappa B p65 and Fos/Jun transcription factors produces potentiated biological function. EMBO J 1993, 12:3879-3891

43. Shyu YJ, Suarez CD, Hu CD: Visualization of AP-1 NF-kappaB ternary complexes in living cells by using a BiFC-based FRET. Proc Natl Acad Sci USA 2008, 105:151-156

44. Adcock IM: Transcription factors as activators of gene transcription: AP-1 and NF-kappa B. Monaldi Arch Chest Dis 1997, 52:178-186

45. Grkovich A, Johnson CA, Buczynski MW, Dennis EA: Lipopolysaccharide-induced cyclooxygenase-2 expression in human U937 macrophages is phosphatidic acid phosphohydrolase-1-dependent. J Biol Chem 2006, 281:32978-32987

46. Baranova I, Vishnyakova T, Bocharov A, Chen Z, Remaley AT, Stonik J, Eggerman TL, Patterson AP: Lipopolysaccharide down regulates both scavenger receptor B1 and ATP binding cassette transporter A1 in RAW cells. Infect Immun 2002, 70:2995-3003 